\title{
Gold(I), phosphanes and alkynyls: the perfect allies in the search for luminescent derivatives
}

\author{
M. Carmen Blanco, ${ }^{[[a, b]}$ Jéssica Cámara,${ }^{[a]}$ Vanesa Fernández-Moreira, ${ }^{[a]}$ Antonio Laguna,${ }^{[a]} \mathrm{M}$. \\ Concepción Gimeno*[a] \\ Dedication ((optional))
}

\begin{abstract}
A family of mixed phosphine/alkynyl gold(I) complexes has been prepared by addition of $\mathrm{PPh}_{3}$ or $\mathrm{PPh}_{2} \mathrm{py}$ to suspensions of the polymeric species $\left[A u(C \equiv C R)_{n}\right](R=P h, 2-$ py) and $\left[\mathrm{Au}_{2}\left(\mathrm{C} \equiv \mathrm{C}\left(\mathrm{CH}_{2}\right)_{3} \mathrm{C} \equiv \mathrm{C}\right)\right]_{\mathrm{n}}$. The complexes obtained are luminescent both at room and low temperature, in solution and in solid state. The emissions are assigned to intraligand transitions associated to the $\mathrm{C} \equiv \mathrm{C}$ moieties or relative to ${ }^{3}[\sigma(\mathrm{Au}$ $\left.\mathrm{P}) \rightarrow \pi^{*}(\mathrm{C} \equiv \mathrm{Cpy})\right]$ transitions. The crystal structure of the dinuclear derivative $\left[\mathrm{Au}_{2}\left(\mathrm{C} \equiv \mathrm{C}\left(\mathrm{CH}_{2}\right)_{3} \mathrm{C} \equiv \mathrm{C}\right)\left(\mathrm{PPh}_{2} \text { py }\right)_{2}\right]$ shows the presence of dimers stabilized by intermolecular aurophilic interactions.
\end{abstract}

\section{Introduction}

Gold alkynyl moieties play a key role as building blocks for the construction of big molecular assemblies. This special relevance as ligands in supramolecular chemistry is based on three special characteristics: their linearity, the wide variety of coordination modes of the unsaturated bond and the ability of gold(I) to establish metallophillic interactions, mainly with other gold atoms (aurophilicity). ${ }^{[1]}$ These interactions, based on the strong relativistic effects displayed by gold atoms, are especially important because of their contribution in molecular aggregation in both solid state and solution, similar in energy and directionality to hydrogen bonds. ${ }^{[2]}$ The structures thus obtained present interesting properties among which stand out their physical properties such as nonlinear optical behavior, photoemissive properties and liquid-crystalline properties, in addition of the interesting catalytic properties. ${ }^{[3]}$

Phosphanes are another group of ligands that have been extensively used to prepare luminescent gold(I) species. These ligands can favor the emissive properties in addition to improving the solubility of high nuclear species. ${ }^{[4]}$

In the last years we have worked in the synthesis and study of gold complexes that combine both phosphane and alkynyl

[a] Dr. M. Carmen Blanco, Prof. Dr. M. Concepción Gimeno, Dr. Jéssica Cámara, Dr. Vanesa Fernández-Moreira, Prof. Dr. Antonio Laguna.

Departamento de Química Inorgánica, Instituto de Síntesis Química y Catálisis Homogénea (ISQCH), CSIC-Universidad de Zaragoza, 50009 Zaragoza, Spain

E-mail: mablanor@unizar.es, gimeno@unizar.es, http://www.isqch.unizar-csic.es/ISQCHportal/grupos.do?id=1 http://conchita-gimeno.webs.com/

[b] Dr. M. Carmen Blanco

Centro Universitario de la Defensa

Academia General Militar

50090 Zaragoza, Spain ligands and have described several structural frameworks with interesting properties. ${ }^{[5]}$ Herein, we report on the synthesis of a new family of gold(I) complexes bearing different phosphane or alkynyl ligands. These complexes present luminescent properties at low and room temperature, both in solid and solution states.

\section{Results and Discussion}

A convenient procedure to synthesize gold alkynyl complexes with different ancillary ligands is the reaction of the polymeric derivatives $\left[\mathrm{Au}(\mathrm{C} \equiv \mathrm{CR})_{\mathrm{n}}\right](\mathrm{R}=\mathrm{Ph}, 2$-py $)$ with the corresponding ligand. These species have been used as starting materials and have been prepared as described in the bibliography. ${ }^{[6]}$

We have previously studied the reactivity of $\left[\mathrm{Au}(\mathrm{C} \equiv \mathrm{CR}) \mathrm{PPh}_{3}\right](\mathrm{R}$ $=\mathrm{Ph}, 2$-py) derivatives with excellent results ${ }^{[5]}$ and then we have decided to prepare analogue compounds by modification of the phosphane ligand. Thus, two new derivatives have been prepared changing the phosphane for the 2diphenylphosphanepyridine $\left(\mathrm{PPh}_{2} \mathrm{py}\right)$ ligand.

$$
\begin{aligned}
{[\mathrm{Au}(\mathrm{C} \equiv \mathrm{CR})]_{\mathrm{n}}+\mathrm{PPh}_{2} \text { py } \frac{\mathrm{CH}_{2} \mathrm{Cl}_{2}}{3 \mathrm{~h}} \longrightarrow\left[\mathrm{Au}(\mathrm{C} \equiv \mathrm{CR})\left(\mathrm{PPh}_{2} \mathrm{py}\right)\right] } \\
\mathrm{R}=\mathrm{Ph}, 2 \text {-py }
\end{aligned}
$$

Scheme 1. Synthesis of complexes 1 and 2.

Complexes 1 and $\mathbf{2}$ are obtained as air- and moisture -stable pale yellow solids. Both are soluble in halogenated solvents and insoluble in diethyl ether or hexane. The IR spectra show the weak absorptions arising from the vibration of the $\mathrm{C} \equiv \mathrm{C}$ bond at $\mathrm{v}$ $=2112$ (1) and 2116 (2) $\mathrm{cm}^{-1}$, typical for $\mathrm{C} \equiv \mathrm{C}$ triple bonds coordinated to gold $(\mathrm{I}){ }^{[7]}$

The ${ }^{31} P\left\{{ }^{1} H\right\}$ NMR spectra show a singlet associated to the ligand $\mathrm{PPh}_{2} \mathrm{py}$ at $\delta=41.3$ (1) and 41.0 (2) ppm, respectively. The resonances observed in the ${ }^{1} \mathrm{H}$ NMR spectra agree with the presence of protons belonging to aromatic moieties, both from pyridine and phenyl rings. In the mass spectra (MALDI+) the fragments corresponding to the molecular peaks $\left[\mathrm{Au}_{2}(\mathrm{C} \equiv \mathrm{CR})\left(\mathrm{PPh}_{2} \mathrm{py}\right)_{2}\right]^{+}$at $\mathrm{m} / z \quad 1021$ (1) and 1022 (2) are observed (for more details see the Experimental Section). Although no crystal structure determination of these complexes have been achieved, due to the similarity with other compounds already described, as the well-known $\left[\mathrm{Au}(\mathrm{C} \equiv \mathrm{CPh}) \mathrm{PPh}_{3}\right]$, a similar structure with a linear coordination for the gold atom is proposed. 
To introduce a new structural modification we decided to prepare a dinuclear complex using the diphosphane ligand dppe (bis(diphenylphosphane)ethane) following the methodology already commented (Scheme 2).

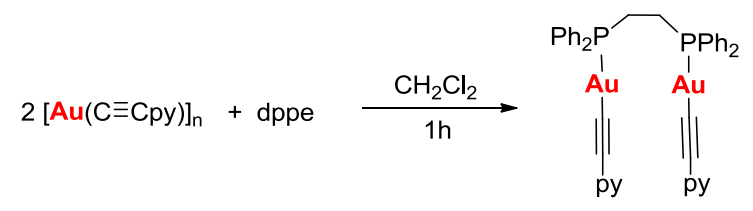

(3)
Scheme 2. Synthesis of complex 3

The dinuclear derivative $\mathbf{3}$ was obtained as an air- and moisture -stable pale yellow solid. The compound is soluble in acetone and halogenated solvents and insoluble in others as hexane or diethyl ether. The vibration of the $\mathrm{C} \equiv \mathrm{C}$ bond arises as a very weak band at $v=2119 \mathrm{~cm}^{-1}$ in its IR spectrum. In the ${ }^{31} \mathrm{P}\left\{{ }^{1} \mathrm{H}\right\}$ NMR spectrum a broad singlet is observed as consequence of the equivalence between the two phosphorus atoms for the ligand dppe, at $\delta=39.7 \mathrm{ppm}$. In the ${ }^{1} \mathrm{H}$ NMR spectrum, in addition to the resonances arising at the protons of the aromatic groups, the equivalent methylene protons of the dppe ligand are observed at $2.65 \mathrm{ppm}$. The highest peak in the MS-MALDI+ spectrum is the fragment that comes about the loss of an alkyne group, [M-(C三Cpy)] at $m / z 894$.

The crystal structure of $\mathbf{3}$ was established by X-ray diffraction and is shown in Figure 1. Adequate monocrystals were obtained by slow diffusion of a dichloromethane solution of $\mathbf{3}$ in hexane.
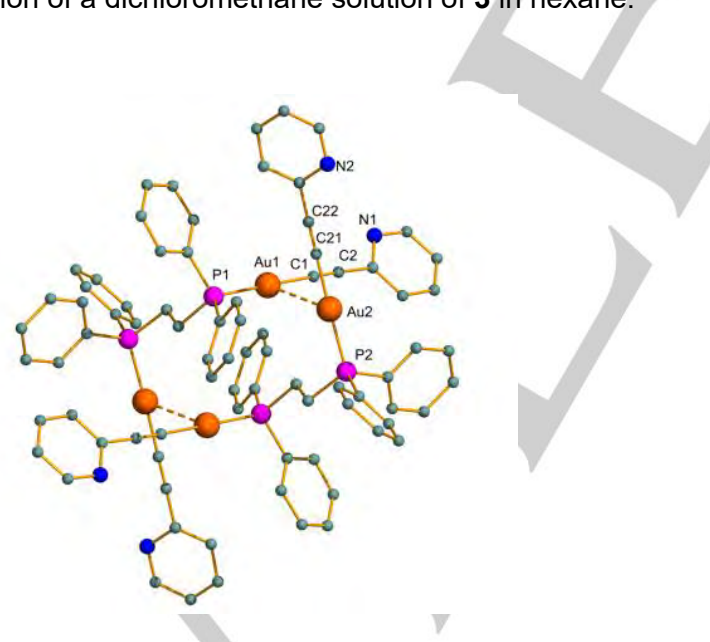

Figure 1. Molecular crystal structure of $3 ; \mathrm{H}$ atoms are omitted for clarity. Selected bond lengths $(\AA)$ and angles $\left({ }^{\circ}\right)$ : $A u(1)-C(1) 2.063(9), A u(1)-P(1)$ 2.275(2), $\quad A u(1)-A u(2) \quad 3.0387(13), \quad A u(2)-C(21) \quad 2.037(10), \quad A u(2)-P(2)$ 2.278(2), $\quad \mathrm{C}(1)-\mathrm{C}(2) \quad 1.115(13), \quad \mathrm{C}(21)-\mathrm{C}(22) \quad 1.176(13) ; \quad \mathrm{C}(1)-\mathrm{Au}(1)-\mathrm{P}(1)$ 174.5(2), C(21)-Au(2)-P(2) 175.2(3)

The crystal structure shows the compound as a dimer stabilized by the presence of intermolecular gold-gold interactions with a distance of 3.0387(13) $\AA$. However, the gold atoms of the same molecule are placed at distances too far to be considered as an aurophilic interaction, unlike the derivative $\left[\mathrm{Au}_{2}\left(\mathrm{C} \equiv \mathrm{CC}_{5} \mathrm{H}_{4} \mathrm{~N}\right)_{2}(\mathrm{dppe})\right]$ (with the nitrogen atom of the pyridine is in para position) with distances of 3.215 (2) $\AA$. The presence of a intramolecular aurophilic interaction produces a totally different supramolecular structure consisting in an infinite chain polymer ${ }^{[8]}$ However, the formation of a tetranuclear species through intramolecular gold-gold interactions is similar to that found in the analogous complex with chloride ligands, $\left[\mathrm{Au}_{2} \mathrm{Cl}_{2}(\mathrm{dppe})\right]^{[9]}$ The gold atoms of complex 3 maintain a linear coordination of the $\mathrm{d}^{10}$ ions, slightly distorted with $\mathrm{P}-\mathrm{Au}-\mathrm{C}$ angles of $174.5(2)$ and $175.2(3)^{\circ}$. The alkyne groups of the two different units, for which gold atoms establish the interactions, are disposed in an orthogonal fashion to each other. The Au-C distances are 2.063(9) and 2.037(10) $\AA$, and the Au-P bond lengths of 2.275(2) and 2.278(2) $\AA$ fall within the expected ranges for these bonds. ${ }^{[10]}$

Compounds 1 and 2 are mononuclear with monoalkynyl and monophosphane ligands, whereas complex $\mathbf{3}$ is dinuclear, with monoalkynyl and bidentate diphosphane ligands. In order to search for a mixed situation, we decided to prepare dinuclear complexes bearing dialkynyl and monophosphane ligands as $\left[\mathrm{Au}_{2}\left(\mathrm{C} \equiv \mathrm{C}\left(\mathrm{CH}_{2}\right)_{3} \mathrm{C} \equiv \mathrm{C}\right)\right]_{n}$ (Scheme 3). For its preparation a similar procedure to the published methods with other alkynyl substrates was applied:

$2[\mathrm{AuCl}($ tht $)]+6 \mathrm{NEt}_{3}+\mathrm{HC} \equiv \mathrm{C}\left(\mathrm{CH}_{2}\right)_{3} \mathrm{C} \equiv \mathrm{CH} \frac{\mathrm{CH}_{2} \mathrm{Cl}_{2}}{3 \mathrm{~h}}-\left[\mathrm{Au}_{2}\left(\mathrm{C} \equiv \mathrm{C}\left(\mathrm{CH}_{2}\right)_{3} \mathrm{C} \equiv \mathrm{C}\right)\right]_{n}$

Scheme 3. Synthesis of $\left[\mathrm{Au}_{2}\left(\mathrm{C} \equiv \mathrm{C}\left(\mathrm{CH}_{2}\right)_{3} \mathrm{C} \equiv \mathrm{C}\right)\right]_{\mathrm{n}}$.

This polymeric derivative is air- and moisture-stable pale orange solid and show poor solubility in most organic solvents. Additionally, it must be very carefully managed for its potential explosive behavior, as is already described for some goldalkynyl derivatives. ${ }^{[11]}$ Thus, the reaction of this starting material $\left[\mathrm{Au}_{2}\left(\mathrm{C} \equiv \mathrm{C}\left(\mathrm{CH}_{2}\right)_{3} \mathrm{C} \equiv \mathrm{C}\right)\right]_{\mathrm{n}}$ in a $1: 2$ ratio with the corresponding monophoshanes affords compounds $\mathbf{4}$ and $\mathbf{5}$ as is shown in Scheme 4.



$$
\begin{aligned}
& \mathrm{PR}_{3}=\mathrm{Ph}_{3} \text { (4), } \mathrm{PPh}_{2} \text { py (5) }
\end{aligned}
$$

Scheme 4. Synthesis of complexes $\mathbf{4}$ and $\mathbf{5}$.

Complexes 4 and $\mathbf{5}$ were obtained as air-, light- and moisturewhite (4) and pale orange (5) stable solids, respectively. Both are soluble in halogenated solvents or acetone and insoluble in diethyl ether or hexane. In these cases, the $v(C \equiv C)$ bands are not observed. This behavior, although unexpected, has already been previously described for other gold-alkynyl examples. ${ }^{[10 b]}$ 
The most relevant data of their ${ }^{1} \mathrm{H}$ and ${ }^{31} \mathrm{P}\left\{{ }^{1} \mathrm{H}\right\}$ have been collected in the Table 1 . The ${ }^{1} \mathrm{H}$ NMR spectra show the resonances due to the protons of the phenyl rings and additionally a triplet and a quartet for the propyl moiety. The ${ }^{31} \mathrm{P}$ NMR spectra present a unique resonance for the equivalent phosphorus atoms.

Table 1. ${ }^{1} \mathrm{H}$ and ${ }^{31} \mathrm{P}\left\{{ }^{1} \mathrm{H}\right\}$ NMR data for compounds 4 and 5.

\begin{tabular}{|c|c|c|c|c|}
\hline \multirow{2}{*}{$\mathrm{PR}_{3}$} & \multicolumn{3}{|c|}{ NMR ${ }^{1} \mathrm{H}(\mathrm{ppm})$} & \multirow{2}{*}{$\begin{array}{c}\text { NMR } \\
{ }^{31} P\left\{{ }^{1} H\right\}\end{array}$} \\
\hline & $\mathbf{H}_{2} \mathbf{C}-\mathrm{CH}_{2}-\mathrm{CH}_{2}$ & $\mathrm{H}_{2} \mathrm{C}-\mathrm{CH}_{2}-\mathrm{CH}_{2}$ & $\begin{array}{l}{ }^{3} J_{H-H} \\
(H z)\end{array}$ & \\
\hline $\begin{array}{c}\mathrm{PPh}_{3} \\
\text { (4) }\end{array}$ & $2.54(\mathrm{t})$ & $1.89(q)$ & 7.3 & 42.5 \\
\hline $\begin{array}{c}\mathrm{PPh}_{2} \mathrm{py} \\
\text { (5) }\end{array}$ & $2.55(\mathrm{t})$ & $1.89(q)$ & 7.2 & 41.5 \\
\hline
\end{tabular}

The stoichiometry of these complexes has also been supported by the mass spectroscopy (MALDI) spectra, which show the molecular peaks of both compounds at $\mathrm{m} / \mathrm{z} 1009.0(8.7 \%, 4)$ and $m / z 1011.2(27.2 \%, 5)$.

The characterization of the compounds 1-5 has been completed with the study of their optical properties.

\section{Optical properties of the compounds 1-5}

The analysis of these properties will be done separately in function of the alkynyl group present in the molecule: aryl or alkyl type. All of these compounds show emissions, in both solution and solid state.

Firstly, the properties of the aryl-alkynyl compounds will be described. Table 2 shows their absorption values in the UV-vis spectra for $2.5 \cdot 10^{-5} \mathrm{M}$ dichloromethane solutions

Table 2. Absorption values in the UV-vis spectra for 1-3 (dichloromethane solutions $2.5 \cdot 10^{-5} \mathrm{M}$ )

$\left.\begin{array}{|c|c|}\hline \text { Compound } & \lambda_{\max }(\mathrm{nm})\left[\varepsilon\left(\mathrm{dm}^{3} \cdot \mathrm{mol}^{-1} \cdot \mathrm{cm}^{-1}\right)\right] \\ \hline\left[\mathrm{Au}(\mathrm{C} \equiv \mathrm{CPh})\left(\mathrm{PPh}_{2} \mathrm{py}\right)\right](1) & 237(33027), 267(26389) \\ & 283(26050)\end{array}\right)$

Electronic absorption spectra of complexes 1-3 show high energy absorptions in the $230-290 \mathrm{~nm}$ range and show no absorption beyond $320 \mathrm{~nm}$. The free phosphanes have absorption maxima below $270 \mathrm{~nm}$ assigned to intraligand transitions associated with $\pi \rightarrow \pi^{*}$ transitions in the phenyl rings.
These absorptions are also present in the corresponding gold complexes. On this ocassion the consecutive peaks found at 267-283 $\mathrm{nm}$ have an energetic difference around $2100 \mathrm{~cm}^{-1}$, frequency corresponding to the triple bond vibration, consequently these absorptions can be associated to IL transitions $\left(\pi \rightarrow \pi^{*}\right)$ centered on the alkynyl ligand. ${ }^{[8,12]}$ The lower energy absorptions, around $300 \mathrm{~nm}$ correspond to $\sigma \rightarrow \pi$ transitions from the Au-P bond to the antibonding orbitals of the aromatic rings.

The three compounds have emissions both in solution and in the solid-state. Data of these transitions are shown in Tables 3 and 4 , respectively.

Table 3. Spectroscopic data for compounds 1-3 in solution at room temperature and $77 \mathrm{~K}$.

\begin{tabular}{|c|c|c|c|c|}
\hline \multirow{2}{*}{ Compound } & \multicolumn{2}{|c|}{298 K } & \multicolumn{2}{c|}{77 K } \\
\cline { 2 - 5 } & $\begin{array}{c}\text { Excitation } \\
\lambda_{\max } / \mathrm{nm}\end{array}$ & $\begin{array}{c}\text { Emission } \\
\lambda_{\max } / \mathrm{nm}\end{array}$ & $\begin{array}{c}\text { Excitation } \\
\lambda_{\max } / \mathrm{nm}\end{array}$ & $\begin{array}{c}\text { Emission } \\
\lambda_{\max } / \mathrm{nm}\end{array}$ \\
\hline \multirow{2}{*}{$\mathbf{1}$} & 308,340 & 390,443 & 290 & $\begin{array}{c}413,435, \\
443,454, \\
466,478, \\
489^{a}\end{array}$ \\
\hline $\mathbf{2}$ & 313,360 & 440 & 284,305 & $\begin{array}{c}413,435, \\
442,455^{\mathrm{a}}\end{array}$ \\
\hline $\mathbf{3}$ & 340 & 405,450 & 272 & $\begin{array}{c}420,445, \\
460,479^{\mathrm{a}}\end{array}$ \\
\hline
\end{tabular}

${ }^{\mathrm{a} B a n d}$ with vibronic structure

Figure 2 shows the excitation and emission spectra for complexes 1-3 in dichloromethane solution at room temperature.

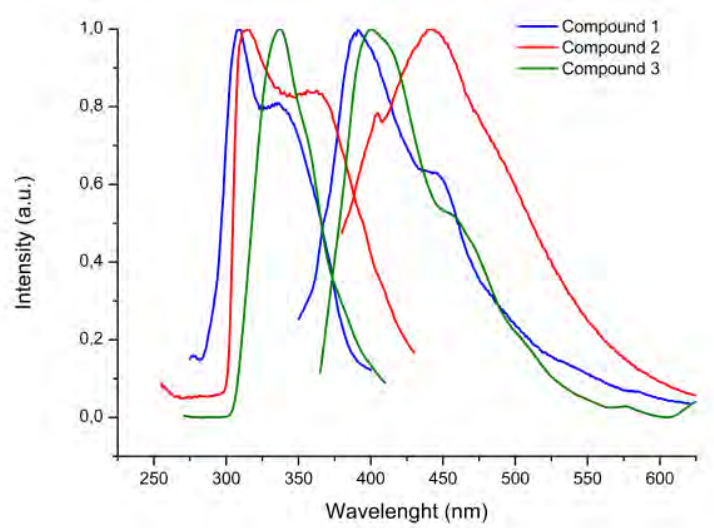

Figure 2. Excitation/emission spectra of complexes 1, 2 and $\mathbf{3}$ in solution.

For these compounds an emission around $440 \mathrm{~nm}$ is found, as in similar compounds such as $\left[\mathrm{Au}(\mathrm{C} \equiv \mathrm{CPh}) \mathrm{PPh}_{3}\right]$ and $\left[\mathrm{Au}(\mathrm{C} \equiv \mathrm{Cpy}) \mathrm{PPh}_{3}\right]$ previously reported. ${ }^{\left[{ }^{[\mathrm{a}, \mathrm{c}]}\right]}$ The origin of this emission is assigned to an intraligand $\pi-\pi^{*}(\mathrm{C} \equiv \mathrm{C})$ or $\sigma(\mathrm{Au}-\mathrm{P})$ - 
$\pi^{*}(\mathrm{C} \equiv \mathrm{C})$ transition. Hence, the same origin is proposed for the emission in derivatives 1 and 2 . Complex 3 is a dinuclear derivative that shows a similar emission pattern to other di-gold derivatives with bridging diphosphanes; ${ }^{[13]}$ an excitation band around $350 \mathrm{~nm}$, with an emission maxima at $405 \mathrm{~nm}$ and a shoulder at $450 \mathrm{~nm}$. The former is likely to be $\pi \rightarrow \pi^{*}$ intraligand transition in the diphosphane and the latter is likely to be $\sigma \rightarrow \pi^{*}$ transition also in the diphosphane or, alternatively, $[\pi \rightarrow \pi *(C \equiv C)]$. The lifetime of $95 \mathrm{~ns}$ for the main emission of complex 3 corroborates its fluorescence nature.

Table 4. Spectroscopic data for compounds 1-3 in solid state.

\begin{tabular}{|c|c|c|c|c|}
\hline \multirow{2}{*}{ Compound } & \multicolumn{2}{|c|}{$298 K$} & \multicolumn{2}{c|}{77 K } \\
\cline { 2 - 5 } & $\begin{array}{c}\text { Excitation } \\
\lambda_{\max } / \mathrm{nm}\end{array}$ & $\begin{array}{c}\text { Emission } \\
\lambda_{\max } / \mathrm{nm}\end{array}$ & $\begin{array}{l}\text { Excitation } \\
\lambda_{\max } / \mathrm{nm}\end{array}$ & $\begin{array}{c}\text { Emission } \\
\lambda_{\max } / \mathrm{nm}\end{array}$ \\
\hline $\mathbf{1}$ & 275,315 & $\begin{array}{c}429,452, \\
467,493^{\mathrm{a}}\end{array}$ & 275,310 & $\begin{array}{c}429,450 \\
460,472, \\
490^{\mathrm{a}}\end{array}$ \\
\hline $\mathbf{2}$ & 311 & 458 & 279,326 & 456 \\
\hline $\mathbf{3}$ & 320,377 & 510 & 322,364 & 447 \\
\hline
\end{tabular}

aBand with vibronic structure.

In the solid state, the emission of the dimeric derivative 3 is shifted up to $510 \mathrm{~nm}$, with an excitation wavelength with maxima at lower energies than in $\mathbf{1}$ and $\mathbf{2}$, suggesting a different origin for this transition. This emission can be been associated to a ${ }^{3}\left[\sigma(\mathrm{Au}-\mathrm{P}) \rightarrow \pi^{*}(\mathrm{C} \equiv \mathrm{Cpy})\right]$ origin, although a contribution of orbitals from the metal atoms cannot be ruled out. The lifetime of $244 \mu \mathrm{s}$ clearly points out a phosphorescent nature of the emission. Figure 3 represents the excitation/emission spectra for complexes 1-3 in the solid state, showing the different energy emissions from blue to yellow.

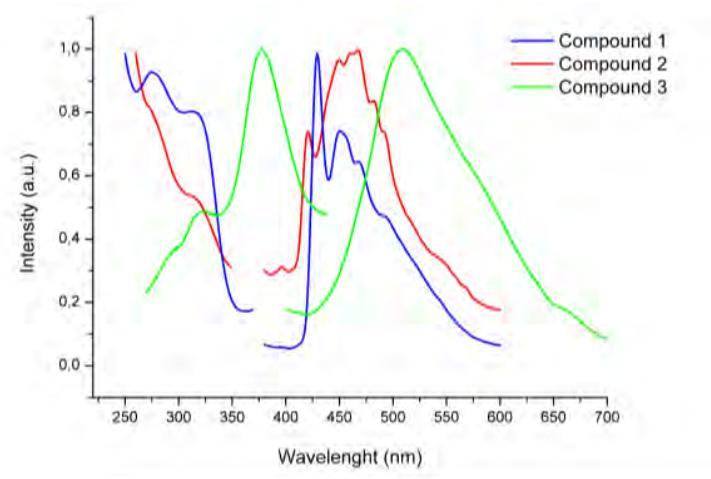

Figure 3. Excitation/emission spectra of complexes 1, 2 and $\mathbf{3}$ in solid state at $298 \mathrm{~K}$.

The second group of complexes includes the derivatives synthesized from the polymeric species $\left[\mathrm{Au}_{2} \mathrm{C} \equiv \mathrm{C}\left(\mathrm{CH}_{2}\right)_{3} \mathrm{C} \equiv \mathrm{C}\right]_{n}$. Table 5 shows the maxima of the UV-vis spectra of $\mathbf{4}$ and $\mathbf{5}$, in addition to the absorptions of the free ligand. The spectra of the complexes show a very intense absorption at $230 \mathrm{~nm}$, also present in the free bisalkyne species, so it is associated with an IL transition $[\pi \rightarrow \pi *(C \equiv C)]$. Compound 5 shows a second maximum at $257 \mathrm{~nm}$ which also appears in the free phosphane spectrum, suggesting another IL transition but centered on the phosphine ligand.

Table 5. Absorption values in the UV-vis spectra for dichloromethane solutions $2.5 \cdot 10^{-5} \mathrm{M}$ of $4-5$.

\begin{tabular}{|l|c|}
\hline Compound & $\begin{array}{c}\lambda_{\max }(\mathrm{nm}) \\
{\left[\varepsilon\left(\mathrm{dm}^{3} \cdot \mathrm{mol}^{-1} \cdot \mathrm{cm}^{-1}\right)\right]}\end{array}$ \\
\hline $\mathrm{HC}=\mathrm{C}\left(\mathrm{CH}_{2}\right)_{3} \mathrm{C}=\mathrm{CH}$ & $230(31773)$ \\
\hline$\left[\mathrm{Au}_{2}\left(\mathrm{C}=\mathrm{C}\left(\mathrm{CH}_{2}\right)_{3} \mathrm{C}=\mathrm{C}\right)\left(\mathrm{PPh}_{3}\right)_{2}\right](4)$ & $230(53455)$ \\
\hline$\left[\mathrm{Au}_{2}\left(\mathrm{C}=\mathrm{C}\left(\mathrm{CH}_{2}\right)_{3} \mathrm{C}=\mathrm{C}\right)\left(\mathrm{PPh}_{2} \mathbf{p y}\right)_{2}\right](5)$ & $\begin{array}{c}233(51871), \\
255(24750)\end{array}$ \\
\hline
\end{tabular}

These complexes are luminescent both in solution and in solid state. The data collected in the study of their luminescence both at room temperature and at $77 \mathrm{~K}$ are summarized in the Tables 6 and 7.

Table 6. Spectroscopic data for compounds 4-5 in dichlometane solution at room temperature and glassed solution.

\begin{tabular}{|c|c|c|c|c|}
\hline \multirow{2}{*}{ Compound } & \multicolumn{2}{|c|}{298 K } & \multicolumn{2}{c|}{77 K } \\
\cline { 2 - 5 } & $\begin{array}{c}\text { Excit. } \\
\lambda_{\max } / \mathrm{nm}\end{array}$ & $\begin{array}{c}\text { Emiss. } \\
\lambda_{\max } \\
/ \mathrm{nm}\end{array}$ & $\begin{array}{c}\text { Excitation } \\
\lambda_{\max } / \mathrm{nm}\end{array}$ & $\begin{array}{c}\text { Emission } \\
\lambda_{\max } / \mathrm{nm}\end{array}$ \\
\hline $\mathbf{H C} \equiv \mathbf{C}\left(\mathbf{C H}_{2}\right)_{3} \mathbf{C} \equiv \mathbf{C H}$ & 305 & 365 & 275,365 & 433 \\
\hline & 315 & 378 & $\begin{array}{c}256,265, \\
273\end{array}$ & $\begin{array}{c}359,376,393 . \\
415,43,444, \\
457,467,480^{a}\end{array}$ \\
\hline $\mathbf{5}$ & 328 & 390 & $\begin{array}{c}276 \\
280,336\end{array}$ & $\begin{array}{c}416,434,444, \\
455,466^{a}\end{array}$ \\
\hline
\end{tabular}

aBand with vibronic structure

Figure 4 represent the excitation and emission of compounds 4 and $\mathbf{5}$ in dichloromethane solution. In solution at room temperature, both compounds show an emission at $390 \mathrm{~nm}$ that can be associated with the transition $[\pi \rightarrow \pi * C \equiv C)]$ in the alkynyl ligand, since the starting ligand also shows such emission. This emission is also found at lower temperature, and, in addition, a second emission appears with the same structured profile as in compounds 1-2, so a similar origin is proposed, ${ }^{3}\left[\sigma(\mathrm{Au}-\mathrm{P}) \rightarrow \pi^{*}(\mathrm{C} \equiv \mathrm{Cpy})\right]$ transitions. 


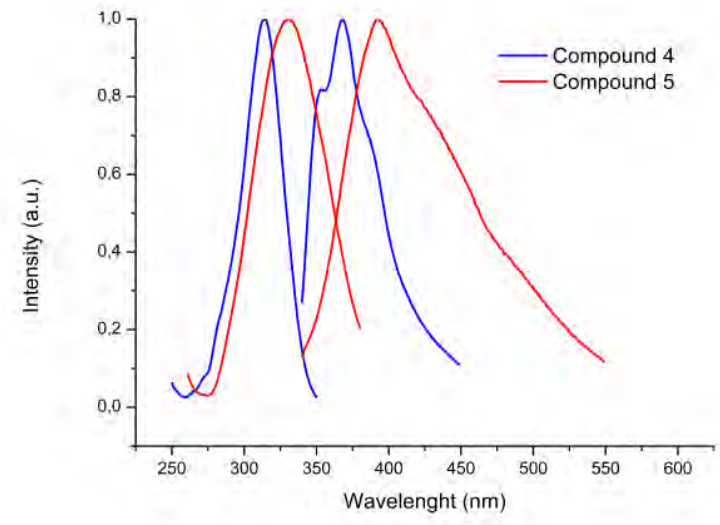

Figure 4. Excitation/emission spectra of complexes 1, 2 and 3 in solid state at $298 \mathrm{~K}$.

Table 7. Spectroscopic data for compounds 4-5 in solid state.

\begin{tabular}{|c|c|c|c|c|}
\hline \multirow{2}{*}{ Compound } & \multicolumn{2}{|c|}{298 K } & \multicolumn{2}{c|}{77 K } \\
\cline { 2 - 5 } & $\begin{array}{c}\text { Excitation } \\
\lambda_{\max } / \mathrm{nm}\end{array}$ & $\begin{array}{c}\text { Emission } \\
\lambda_{\max } / \mathrm{nm}\end{array}$ & $\begin{array}{c}\text { Excitation } \\
\lambda_{\max } / \mathrm{nm}\end{array}$ & $\begin{array}{c}\text { Emission } \\
\lambda_{\max } / \mathrm{nm}\end{array}$ \\
\hline $\mathbf{H C} \equiv \mathbf{C}\left(\mathbf{C H}_{\mathbf{2}}\right)_{3} \mathbf{C} \equiv \mathbf{C H}$ & 328,365 & 363,449 & 370 & 430 \\
\hline $\mathbf{4}$ & 297,313 & 505 & 292,315 & 500 \\
\hline $\mathbf{5}$ & 435 & 500 & 297,393 & 505 \\
\hline
\end{tabular}

Figure 5 represent the excitation and emission of compounds 4 and $\mathbf{5}$ in solid state.

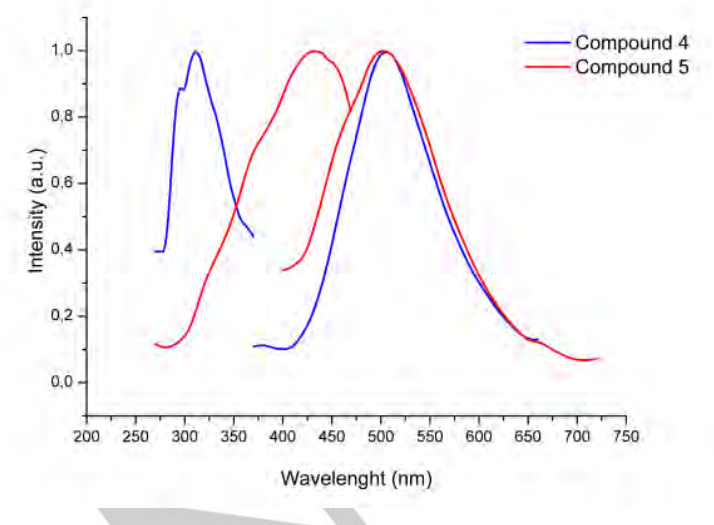

Figura 5. Excitation/emission spectra of complexes $\mathbf{4}$ and $\mathbf{5}$ in solid state at 298 K.

The emission spectrum of the free ligand shows two bands at 360 and $450 \mathrm{~nm}$, whose origins are transitions IL $[\pi \rightarrow \pi *(C \equiv C)]$.
In the gold complexes, this band, both at low and room temperature, is shifted to lower energies, around $500 \mathrm{~nm}$. In addition, it is observed that the emission maximum is not affected by the change in the phosphine ligand. However the excitation maxima is very different for both complexes, whereas in $\mathbf{4}$ is around $\mathbf{3 0 0} \mathrm{nm}$ in complex $\mathbf{5}$ is at much lower energy, 435 $\mathrm{nm}$. Consequently, a different origin may be involved in this transition. For complex 4 because the similarity of the excitation/emission profile with compounds 1 and 2 , a ${ }^{3}[\sigma(A u-P)$ $\left.\rightarrow \pi^{*}(\mathrm{C} \equiv \mathrm{C})\right]$ transition is proposed. The lifetime of $10 \mu \mathrm{s}$ agrees with a phosphorescent nature of the emission. For complex 5 the small Stokes shift and the lifetime of $0.19 \mu$ s indicate a fluorescence nature of the emission. The excitation energy profile of this compound is very broad with a maximun at $435 \mathrm{~nm}$ and it seems that several origins could contribute to the final broad emission, intraligand $\pi \rightarrow \pi *$ transitions both in the alkynyl and in $\mathrm{PPh}_{2}$ py ligands modified by the coordination to the gold centers.

\section{Conclusions}

Coordination of different phosphane and alkynyl ligands to gold atoms has allowed the synthesis of new gold derivatives with interesting optical properties. Five mono- and dinuclear complexes of gold have been synthesized and characterized bearing both mono- and di- alkynyl and phosphine ligands. A dimeric structure was confirmed by crystallographic studies for the dppe complex and was shown to be stabilized by intermolecular gold interactions. The compounds here described show intense room- and low- temperature luminescence both in solution and in the solid state. Both fluorescence and phosphorescence are observed and the emissions are assigned to intraligand transitions associated to the $[\pi \rightarrow \pi *(C \equiv C)]$ or the diphosphane moieties or relative to ${ }^{3}\left[\sigma(A u-P) \rightarrow \pi^{*}(C \equiv C p y)\right]$ transitions.

\section{Experimental Section}

${ }^{1} \mathrm{H}$ and ${ }^{13} \mathrm{C}\left\{{ }^{1} \mathrm{H}\right\}$ NMR spectra, including $2 \mathrm{D}$ experiments, were recorded at room temperature on a BRUKER AVANCE 400 spectrometer $\left({ }^{1} \mathrm{H}, 400\right.$ $\mathrm{MHz},{ }^{13} \mathrm{C}, 100.6 \mathrm{MHz}$ ) or on a BRUKER AVANCE II 300 spectrometer $\left({ }^{1} \mathrm{H}, 300 \mathrm{MHz},{ }^{13} \mathrm{C}, 75.5 \mathrm{MHz}\right)$. Mass spectra were recorded on a BRUKER ESQUIRE 3000 PLUS, with the MALDI technique. Elemental analyses were performed on a Perkin Elmer 2400. The starting materials $[\mathrm{Au}(\mathrm{C} \equiv \mathrm{CPh})]_{\mathrm{n}},[\mathrm{Au}(\mathrm{C} \equiv \mathrm{Cpy})]_{n}$ and $\left[\mathrm{AuC} \equiv \mathrm{C}\left(\mathrm{CH}_{2}\right)_{3} \mathrm{C} \equiv \mathrm{CAu}\right]_{n}$ were prepared following procedures previously reported. ${ }^{[6]}$ All other reagents were commercially available. Solvents were used as received without purification or drying. UV/Vis spectra of 1-5 were recorded using an Evolution 600 spectrophotometer (dichloromethane $5 \times 10^{-5} \mathrm{M}$ solutions). Steady-state photoluminescence spectra were recorded with a JobinYvon Horiba Fluorolog FL-3-11 spectrometer using band pathways of 3 $\mathrm{nm}$ for both excitation and emission and fitted with a JY TBX picosecond detection module. Measurements at $77 \mathrm{~K}$ were done with an Oxford Cryostat Optistat DN. Phosphorescence lifetimes were recorded with an IBH 5000F coaxial nanosecond flashlamp. Fluorescent Lifetimes measurements were recorded with a light-emitting diode (LED) from Horiba Jobin Ybon with pulse duration of 1.2 ns. LED frequencies were 
selected attending to excitations energies. Lifetime data were fitted using DAS6 V6.1 software.

Complex 1: To a solution of $\mathrm{PPh}_{2} \mathrm{py}(0.132 \mathrm{~g}, 0.5 \mathrm{mmol})$ in dichloromethane $(20 \mathrm{~mL}),[\mathrm{Au}(\mathrm{C} \equiv \mathrm{CPh})]_{\mathrm{n}}(0.149 \mathrm{~g}, 0.5 \mathrm{mmol})$ was added. After $40 \mathrm{~min}$ the solution was filtered over celite. The solvent of the following solution was partially removed in vacuo, and diethyl ether was added to afford 1 as a pale yellow solid $(0.199 \mathrm{~g}, 71 \%) .{ }^{31} \mathrm{P}\left\{{ }^{1} \mathrm{H}\right\}$ NMR (300 MHz, HDA, $20 \circ \mathrm{C}): \delta 41.7$ (s, $\mathrm{PPh}_{2}$ py); ${ }^{1} \mathrm{H}$ NMR $(300 \mathrm{MHz}, \mathrm{HDA}, 20$ -C7.15-7.81 (m, 17H Ph+H $\left.\mathrm{H}_{4}(\mathrm{py})+\mathrm{H}_{6}(\mathrm{py})\right), 8.04\left(\mathrm{~m}, \mathrm{H}_{5}\right.$, py), $8.84\left(\mathrm{~d},{ }^{3} \mathrm{~J}_{\mathrm{H} 3}\right.$

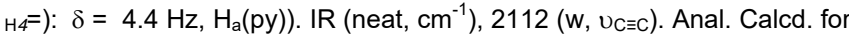
$\mathrm{C}_{25} \mathrm{H}_{19} \mathrm{AuNP}$ (561.4): C, 53.49; H, 3.41; N, 2.50. Found: C, 53.19; $\mathrm{H}$, 3.31; N, 2.36. MS-MALDI+ m/z (\%): $723\left(70,\left[\mathrm{Au}\left(\mathrm{PPh}_{2} \mathrm{py}\right)_{2}\right]^{+}\right) ; 1021(100$, $\left[\mathrm{Au}_{2}(\mathrm{C} \equiv \mathrm{CPh})\left(\mathrm{PPh}_{2} \mathrm{py}_{2}\right]^{+}\right)$.

Complex 2: To a suspension of $[A u(C \equiv C p y)]_{n}(0.150 \mathrm{~g}, 0.5 \mathrm{mmol})$ in dichloromethane $(20 \mathrm{~mL}) \mathrm{PPh}_{2}$ py $(0.132 \mathrm{~g}, 0.5 \mathrm{mmol})$ was added. After $40 \mathrm{~min}$ the solution was filtered over celite. The following solution was concentrated in vacuo, and diethyl ether was added to afford $\mathbf{2}$ as a pale yellow solid $(0.188 \mathrm{~g}, 67 \%) .{ }^{31} \mathrm{P}\left\{{ }^{1} \mathrm{H}\right\} \mathrm{NMR}(300 \mathrm{MHz}, \mathrm{HDA}, 20 \circ \mathrm{C}): \delta 41.0$ (s, $\left.\mathrm{PPh}_{2} \mathrm{py}\right) ;{ }^{1} \mathrm{H}$ NMR $\left(300 \mathrm{MHz}, \mathrm{CDCl}_{3}, 20 \circ \mathrm{C}\right): \delta=7.10$ (ddd, ${ }^{3} \mathrm{~J}_{\mathrm{H} 5-\mathrm{H} 4}=$ $\left.7.6 \mathrm{~Hz},{ }^{3} \mathrm{~J}_{\mathrm{H} 5-\mathrm{H} 6}=4.9 \mathrm{~Hz},{ }^{4} \mathrm{~J}_{\mathrm{H} 5-\mathrm{H} 3}=1.2 \mathrm{~Hz}, \mathrm{H}_{5}, \mathrm{C} \equiv \mathrm{Cpy}\right), 7.33-7.86(\mathrm{~m}, 14 \mathrm{H}$ $\left.\mathrm{Ph}(10)+\mathrm{H}_{6}+\mathrm{H}_{4^{\prime}}+\mathrm{H}_{5^{\prime}}+\mathrm{H}_{6^{\prime}}\right), 8.05\left(\mathrm{~m}, 1 \mathrm{H}, \mathrm{H}_{4}\right), 8.53\left(\mathrm{~d},{ }^{3} \mathrm{~J}_{\mathrm{H}^{\prime}-\mathrm{H} 4^{\prime}}=4.9 \mathrm{~Hz}, \mathrm{H}_{3^{\prime}}\right)$,

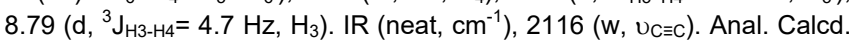
for $\mathrm{C}_{24} \mathrm{H}_{18} \mathrm{AuN}_{2} \mathrm{P}$ (562.4): C, 51.26; H, 3.23; N, 4.98. Found: C, 50.8; H, 3.37; N, 4.81. MS-MALDI+ m/z (\%): 562 (41, [M] $\left.]^{+}\right) ; 723$ (51, $\left[\mathrm{Au}\left(\mathrm{PPh}_{2} \mathrm{py}_{2}\right]^{+}\right) ; 1022\left(100,\left[\mathrm{Au}_{2}(\mathrm{C} \equiv \mathrm{Cpy})\left(\mathrm{PPh}_{2} \mathrm{py}\right)_{2}\right]^{+}\right)$.

Complex 3: To a solution of dppe $(0.100 \mathrm{~g}, 0.25 \mathrm{mmol})$ in dichloromethane $(20 \mathrm{~mL}),[\mathrm{Au}(\mathrm{C} \equiv \mathrm{Cpy})]_{\mathrm{n}}(0.150 \mathrm{~g}, 0.5 \mathrm{mmol})$ was added. After $60 \mathrm{~min}$ the solution was filtered over celite. The solvent of the following solution was partially removed in vacuo, and diethyl ether was added to afford 3 as a white solid $(0.222 \mathrm{~g}, 89 \%) .{ }^{31} \mathrm{P}\left\{{ }^{1} \mathrm{H}\right\} \mathrm{NMR}(300 \mathrm{MHz}$ $\left.\mathrm{CDCl}_{3}, 20 \circ \mathrm{C}\right): \delta=39.7$ (s, $\left.2 \mathrm{P}, \mathrm{dppe}\right) ;{ }^{1} \mathrm{H}$ NMR $\left(300 \mathrm{MHz}, \mathrm{CDCl}_{3}, 20 \circ \mathrm{C}\right):$ $\delta=2.65\left(\mathrm{~s}, 4 \mathrm{H}, \mathrm{CH}_{2}\right), 7.11$ (ddd, ${ }^{3} \mathrm{~J}_{\mathrm{H} 5-\mathrm{H} 4}=7.5 \mathrm{~Hz},{ }^{3} \mathrm{~J}_{\mathrm{H} 5-\mathrm{H} 6}=4.9 \mathrm{~Hz},{ }^{4} \mathrm{~J}_{\mathrm{H} 5-\mathrm{H} 3}=$ $\left.1.2 \mathrm{~Hz}, 2 \mathrm{H}_{5}, \mathrm{py}\right), 7.39-7.76\left(\mathrm{~m}, 22 \mathrm{H}, \mathrm{Ph}(20)+2 \mathrm{H}_{6}(\mathrm{py})\right), 8.52\left(\mathrm{~d},{ }^{3} \mathrm{~J}_{\mathrm{H} 4-\mathrm{H} 3}=\right.$ $\left.4.7 \mathrm{~Hz}, 2 \mathrm{H}_{4}(\mathrm{py})\right), 8.79\left(\mathrm{~d},{ }^{3} \mathrm{~J}_{\mathrm{H} 3-\mathrm{H} 4}=4.7 \mathrm{~Hz}, 2 \mathrm{H}_{3}(\mathrm{py})\right)$. IR (neat, $\left.\mathrm{cm}^{-1}\right), 2119$

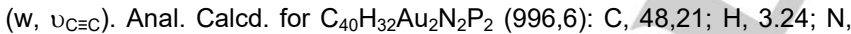
2,81. Found: C, 47.75; H, 3.16; N, 2.87. MS-MALDI+ m/z (\%): 894 (100, $\left[\mathrm{Au}_{2}(\mathrm{C} \equiv \mathrm{Cpy}) \mathrm{dppe}\right), 997\left(27,[\mathrm{M}]^{+}\right) ; 1098\left(22,\left[\mathrm{Au}_{2}(\mathrm{C} \equiv \mathrm{Cpy})_{3} \mathrm{dppe}\right]^{+}\right) ; 1193$ $\left(74,\left[\mathrm{Au}_{3}(\mathrm{C} \equiv \mathrm{Cpy})_{2} \mathrm{dppe}\right]^{+}\right)$.

Complex 4: To a suspension of $\left[\mathrm{AuC} \equiv \mathrm{C}\left(\mathrm{CH}_{2}\right)_{3} \mathrm{C} \equiv \mathrm{CAu}\right]_{\mathrm{n}}(0.193 \mathrm{~g}, 0.4$ $\mathrm{mmol})$ in dichloromethane $(20 \mathrm{~mL}) \mathrm{PPh}_{3}(0.189 \mathrm{~g}, 0.72 \mathrm{mmol})$ was added. After $2 \mathrm{~h}$ the solution was filtered over celite. The following solution was concentrated in vacuo, and diethyl ether was added to afford $\mathbf{4}$ as a white solid $(0.320 \mathrm{~g}, 88 \%) .{ }^{31} \mathrm{P}\left\{{ }^{1} \mathrm{H}\right\}$ NMR $\left(300 \mathrm{MHz}, \mathrm{CDCl}_{3}, 20 \circ \mathrm{C}\right): \delta=42.5(\mathrm{~s}$, $\left.2 \mathrm{P}, \mathrm{PPh}_{3}\right) ;{ }^{1} \mathrm{H}$ NMR $\left(300 \mathrm{MHz}, \mathrm{CDCl}_{3}, 20 \circ \mathrm{C}\right): \delta=1.89\left(\mathrm{q}, 2 \mathrm{H},{ }^{3} \mathrm{~J}_{\mathrm{H}-\mathrm{H}}=7.3\right.$ $\mathrm{Hz}, \mathrm{CH}_{2}-\mathrm{CH}_{2}-\mathrm{CH}_{2}$ ), 2.54 (t, $\left.{ }^{3} \mathrm{~J}_{\mathrm{H}-\mathrm{H}}=7.3 \mathrm{~Hz}, \mathrm{CH}_{2}-\mathrm{CH}_{2}-\mathrm{CH}_{2}\right), 7.37-7.56(\mathrm{~m}$, $30 \mathrm{H}, \mathrm{Ph}), 8.52\left(\mathrm{~d},{ }^{3} \mathrm{~J}_{\mathrm{H} 4-\mathrm{H} 3}=4.7 \mathrm{~Hz}, 2 \mathrm{H}_{4}(\mathrm{py})\right), 8.79\left(\mathrm{~d},{ }^{3} \mathrm{~J}_{\mathrm{H} 3-\mathrm{H} 4}=4.7 \mathrm{~Hz}\right.$, $2 \mathrm{H}_{3}\left(\right.$ py)). IR (neat, $\mathrm{cm}^{-1}$ ): signal $\mathrm{v}_{\mathrm{C} \equiv \mathrm{C}}$ is not observed. Anal. Calcd. for $\mathrm{C}_{43} \mathrm{H}_{36} \mathrm{Au}_{2} \mathrm{P}_{2}$ (1008,64): C, 51,20; $\mathrm{H}, 3.60$. Found: C, 51.34; H, 3.72. MS$\mathrm{MALDI}+\mathrm{m} / \mathrm{z}(\%): 721\left(100,\left[\mathrm{Au}\left(\mathrm{PPh}_{3}\right)_{2}\right]^{+}, 1009\left(9,[\mathrm{M}]^{+}\right) ; 1467(10\right.$, $\left.\left[\mathrm{Au}_{3}\left(\mathrm{C} \equiv \mathrm{C}\left(\mathrm{CH}_{2}\right)_{3} \mathrm{C} \equiv \mathrm{C}\right)\left(\mathrm{PPh}_{3}\right)_{3}\right]^{+}\right)$.

Complex 5: To a solution of $\mathrm{PPh}_{2} \mathrm{py}(0.190 \mathrm{~g}, 0.72 \mathrm{mmol})$ in dichloromethane $(20 \mathrm{~mL}),\left[\mathrm{AuC} \equiv \mathrm{C}\left(\mathrm{CH}_{2}\right)_{3} \mathrm{C} \equiv \mathrm{CAu}\right]_{\mathrm{n}}(0.193 \mathrm{~g}, 0.4 \mathrm{mmol})$ was added. After $60 \mathrm{~min}$ the solution was filtered over celite. The solvent of the following solution was partially removed in vacuo, and diethyl ether was added to afford 5 as a pale orange $(0.309 \mathrm{~g}, 85 \%) .{ }^{31} \mathrm{P}\left\{{ }^{1} \mathrm{H}\right\}$ NMR $\left(300 \mathrm{MHz}, \mathrm{CDCl}_{3}, 20 \circ \mathrm{C}\right): \delta=41.5\left(\mathrm{~s}, 2 \mathrm{P}, \mathrm{PPh}_{2} \mathrm{py}\right) ;{ }^{1} \mathrm{H} \mathrm{NMR}(300 \mathrm{MHz}$, $\left.\mathrm{CDCl}_{3}, 20 \circ \mathrm{C}\right): \delta=1.89\left(\mathrm{q},{ }^{3} \mathrm{~J}_{\mathrm{H}-\mathrm{H}}=7.2 \mathrm{~Hz}, 2 \mathrm{H}, \mathrm{CH}_{2}-\mathrm{CH}_{2}-\mathrm{CH}_{2}\right), 2.55\left(\mathrm{t},{ }^{3} \mathrm{~J}_{\mathrm{H}-}\right.$ $\left.\mathrm{H}=7.3 \mathrm{~Hz}, 4 \mathrm{H}, \mathrm{CH}_{2}-\mathrm{CH}_{2}-\mathrm{CH}_{2}\right), 7.33\left(\mathrm{~m}, 2 \mathrm{H}_{4}(\mathrm{py})\right), 7.37-7.80(\mathrm{~m}, \quad 22$, $\left(2 \mathrm{OH}(\mathrm{Ph})+2 \mathrm{H}_{6}(\mathrm{py})\right), 8.06\left(\mathrm{~m}, 2 \mathrm{H}_{5}(\mathrm{py})\right), 8.75\left(\mathrm{~d},{ }^{3} \mathrm{~J}_{\mathrm{H} 3-\mathrm{H} 4}=4.7 \mathrm{~Hz}, 2 \mathrm{H}_{3}(\mathrm{py})\right)$.
IR (neat, $\mathrm{cm}^{-1}$ ): signal $\mathrm{v}_{\mathrm{C} \equiv \mathrm{C}}$ is not observed. Anal. Calcd. for $\mathrm{C}_{41} \mathrm{H}_{34} \mathrm{Au}_{2} \mathrm{~N}_{2} \mathrm{P}_{2}$ (1010,66): C, 48,73; H, 3.39; N, 2.77. Found: C, 48.31; $\mathrm{H}$ 3.45; N, 2.89. MS-MALDI+ m/z (\%): 723 (96, $\left[\mathrm{Au}\left(\mathrm{PPh}_{2} \mathrm{py}\right)_{2}\right]^{+}, 1011(27$, $\left.[\mathrm{M}]^{+}\right) ; 1207\left(100,[\mathrm{M}+\mathrm{Au}]^{+}\right)$.

\section{Crystal Structure Determinations.}

Data were registered on an Xcalibur diffractometer. The crystals were mounted in inert oil on glass fibres and transferred to the cold gas stream of the diffractometer. Data were collected using monochromated MoKa radiation $(\lambda=0.71073)$ in $\omega$-scans. Absorption correction based on multiple scans was applied with the program SADABS. The structure weas solved by direct methods and refined on $F^{2}$ using the program SHELXL-97. ${ }^{[43]}$ All non-hydrogen atoms were refined anisotropically. Hydrogen atoms were included using a riding model. CCDC 1581498 (3) contains the supplementary crystallographic data. These data can be obtained free of charge by The Cambridge Crystallography Data Center.

\section{Acknowledgements}

Authors thank the Ministerio de Economía y Competitividad (MINECO-FEDER CTQ2016-75816-C2-1-P) and Gobierno de Aragón-Fondo Social Europeo (E77) for financial support.

Keywords: gold $\bullet$ phosphine $\cdot$ alkynyl $\bullet$ luminiscence

[1] (a) E. C. Constable, C. E. Housecroft, M. K. Kocik, J. A. Zampese Polyhedron 2011, 30, 2704-2710; (b) P. Pyykkö, Chem. Rev. 1997, 97 597-636; (c) H. Schmidbaur, A. Schier, Chem. Soc. Rev. 2012, 41 370-412; (d) H. Schmidbaur, A. Schier, Chem. Soc. Rev. 2008, 37 1931-1951.

[2] P. Pyykkö, Y-F. Zhao, Angew. Chem. Int. Ed. Engl. 1991, 30, 604-605.

[3] (a) J. C. Lima, L. Rodríguez, Chem. Soc. Rev. 2011, 40, 5442-5456. (b) A. M. Asiri, A. S. K. Hashmi, Chem. Soc. Rev. 2016, 45, 4471-4503. (c) C. J. V. Halliday, J. M. Lynam, Dalton Trans. 2016, 45, 12611-12626. (d) M. B. Nielsen, Synthesis 2016, 48, 2732-2738. (e) D. Li, X. Hong, C M. Che, W. C. Lo, S. M. Peng, J. Chem. Soc. Dalton Trans. 1993, 19 2929-2932.

[4] (a) V. Fernández-Moreira, J. Cámara, E. S. Smirnova, I. O. Koshevoy, A. Laguna, S. P. Tunik, M. C. Blanco, M. C. Gimeno, Organometallics 2016, 35, 1141-150. (b) H. X. Zhang, C. M. Che, Chem. Eur. J. 2001, 7 4887-4893. (c) M. Frik, J. Jiménez, I. García, L. R. Falvello, S. AbiHabib, K. Suriel, T. R. Muth, M. Contel, Chem. Eur. J. 2012, 18, 3659 3674. (d) S. J. Shieh, X. Hong, S. M. Peng, C. M. Che, J. Chem. Soc. Dalton Trans. 1994, 20, 3067-3068. (e) X. L. Li, K. J. Zhang, J. J. Li, X X. Cheng, Z. N. Chen, Eur. J. Inorg. Chem. 2010, 3449-3457. (f) J. Cámara, O. Crespo, M. C. Gimeno, I. O. Koshevoy, A. Laguna, I. Ospino, E. S. Smirnova, S. P. Tunik, Dalton Trans. 2012, 41, 1389113898.

[5] (a) M. C. Blanco, J. Cámara, M. C. Gimeno, P. G. Jones, A. Laguna, J M. López-de-Luzuriaga, M. E. Olmos, M. D. Villacampa, Organometallics 2012, 31, 2597-2605. (b) M. C. Blanco, J. Cámara, M C. Gimeno, A. Laguna, S. L. James, M. C. Lagunas, M. D. Villacampa, Angew. Chem. Int. Ed. 2012, 51, 9777-9779. (c) V. W.-W. Yam, S. W. K. Choi, J. Chem. Soc., Dalton Trans.1996, 4227-4232.

[6] G. E. Coates, C. Parkin, J. Chem. Soc. 1962, 3220-3226.

[7] M. Ferrer, L. Rodríguez, O. Rossell, F. Pina, J. C. Lima, M. F. Bardia X. Solans, J. Organomet. Chem. 2003, 678, 82-89.

[8] M. Ferrer, A. Gutiérrez, L. Rodríguez, O. Rossell, J. C. Lima, M. FontBardia, X. Solans. Eur. J. Inorg. Chem. 2008, 2899-2909. 
[9] (a) P. A. Bates, J. M. Waters, Inorg. Chim. Acta 1985, 98, 125-129; (b) D. S. Eggleston, D. F. Chodosh, G. R. Girard, D. T. Hill, Inorg. Chim Acta 1985, 108, 221-126.

[10] (a) H. Lang, S. köcher, S. Back, G. Rheinwald, G. Van Boten. Organometallics 2001, 20, 1968-1972. (b) J. Vicente, M. T. Chicote, M. M. Álvarez-Falcón, P. G. Jones, Organometallics 2005, 24, 4666-4675.

[11] R. Nast. Coord. Chem. Rev. 1982, 47, 89-124.

[12] V. W.-W. Yam, S. W.-K. Choi, K.-K. Cheung, Organometallics 1996, 15, 1734-1739.

[13] K. L. Cheung, S. K. Yip, V. W. W. Yam, J. Organomet. Chem. 2004, $689,4451-4462$
[14] CysAlisPro, Version 1.171.35.11; Agilent Technologies. Multiscan absorption correction with SCALE3 ABSPACK scaling algorithm.

[15] G. M. Sheldrick. SHELXL, Acta Cryst. 2008, A64, 112-122. 


\section{FULL PAPER}

Coordination of different phosphane and alkynyl ligands to gold atoms has allowed the synthesis of new mono and dinuclear gold derivatives with interesting optical properties. The compounds show intense luminescence both in solution and in the solid state. Both fluorescence and phosphorescence are observed and the emissions are assigned to intraligand transitions associated to the alkynyl or diphosphane moieties or relative to ${ }^{3}\left[\sigma(\mathrm{Au}-\mathrm{P}) \rightarrow \pi^{\star}(\mathrm{C} \equiv \mathrm{Cpy})\right]$ transitions.

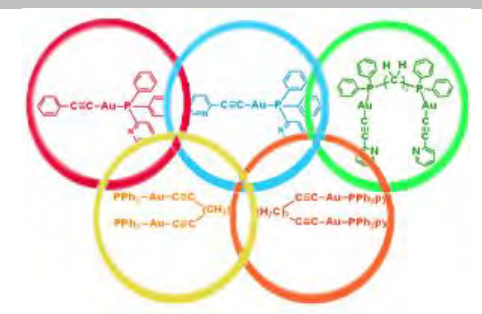

\section{Luminescence}

Jéssica Cámara, M. Carmen Blanco, * Antonio Laguna, M. Concepción Gimeno, *

\section{Page No. - Page No.}

Gold(I), phosphanes and alkynyls: perfect allies for searching luminescent derivatives 